\title{
Attachment of 2,2-bipyridine onto a silica gel for application as a seques- tering agent for copper, cadmium and lead ions from an aqueous medium
}

\author{
Elton J. Souza ${ }^{1}$, Valtair M. Cristante ${ }^{2}$, Pedro M. Padilha, ${ }^{2,4}$, Sonia M.A. Jorge ${ }^{2}$, Marco A.U. Martines ${ }^{3}$, \\ Rafael I.V. Silva ${ }^{2}$, Devaney R. Carmo ${ }^{1}$, Gustavo R. Castro ${ }^{2 *}$ \\ ${ }^{1}$ Departamento de Física e Química, FEIS/UNESP-Univ. Estadual Paulista, C.P. 31, 15385-000, Ilha Solteira, SP, Brazil \\ ${ }^{2}$ Departamento de Química e Bioquímica, IB-UNESP-Univ. Estadual Paulista, C.P.510, 18618-000 Botucatu, SP, Brazil \\ ${ }^{3}$ Departamento de Química, UFMS, C.P. 549, 79074-460, Campo Grande, MS, Brazil \\ ${ }^{4}$ INCT de Bioanalítica - UNICAMP, C.P. 6154, 13084-971 Campinas, SP, Brazil \\ "Corresponding author: e-mail: castrogr@ibb.unesp.br
}

\begin{abstract}
A method was developed to attach 2,2-bipyridine (BP) onto a silica gel surface by a two-step reaction. The first step consisted of a reaction between the matrix and a silylating agent, 3-chloropropyltrimethoxysilane. In the second step of the reaction, a ligand molecule was attached onto Si-CPTS, yielding the product Si-BP. The modified material contained $0.431 \pm 0.01 \mathrm{mmol}$ of 2,2-bipyridine per gram of modified silica, as confirmed by FT-IR spectra of the proposed structure. The surface modification was characterized by the BET technique, which revealed a decrease in the surface area from 614 to $450 \mathrm{~m}^{2} \mathrm{~g}^{-1}$. The series of adsorption isotherms for the metal ions were adjusted to fit a modified Langmuir equation. The maximum number of moles of copper, cadmium and lead ions adsorbed was $0.64,0.53$, and $0.54 \mathrm{mmol}$ $\mathrm{g}^{-1}$, respectively. The surface saturation was calculated as $\phi$ fraction and the values obtained, $\mathrm{Cu}(\mathrm{II})=$ $1.160, \mathrm{Cd}(\mathrm{II})=1.044$ and $\mathrm{Pb}(\mathrm{II})=0.997$, suggest a type $1: 1$ metal-ligand complex.
\end{abstract}

Keywords: 2,2-Bipyridine, silica gel, adsorption, metal ions.

\section{INTRODUCTION}

In the last two decades, human activities have severely impacted the quality of natural water resources by discharging a wide variety of pollutants directly into rivers ${ }^{1-4}$ and streams or via sewage treatment plants that are not completely effective in removing species such as heavy metals ${ }^{5}$. Moreover, the large-scale production of food for the continually growing human population has become another major source of metal pollution due to percolation or leaching, since metals are present in fertilizers as constituents or contaminants.

In this context, industrial activities, mining, sewage and farming contribute to increase the concentrations of metal in natural water bodies. The nondegradability of these species is responsible for the process of accumulation occurring in the food chain and its adverse effects on living organisms.

Modified silica-based materials have been synthesized and applied in several fields of research, including medicine ${ }^{6-8}$ and chemistry, as stationary phases for liquid chromatography ${ }^{9,10}$ and sequestering agents for metal ions in aqueous and ethanol media ${ }^{11-14}$.

Their application stems from the fact that the surface reactivity and large surface area of silica, when coupled to a sol-gel process, allow for the synthesis of materials with desirable characteristics ${ }^{15}$. With regard to the application of silica in metal sequestration, its high surface area is one of its most important characteristics because it allows large quantities of ligand molecules to be grafted onto the silica matrix ${ }^{\mathbf{1 6}}$. Recent works report the high sorption capacity of modified mesoporous silica and its large surface area of more than $700 \mathrm{~m}^{2} \mathrm{~g}^{-1} \mathbf{1 7 , 1 8}$.

The modification of silica surface through the attachment of a ligand molecule containing Lewis base as an adsorption site can be achieved by a silanization procedure involving covalent grafting followed by a second step involving its reaction with an organic ligand molecule.
A major advantage of this procedure is the possibility of developing a modified material which is selective for some metal ions, depending on the type of base (hard, soft, or intermediate) ${ }^{\mathbf{1 9}}$ in the molecule.

In this work, silica gel with a high surface area was prepared via the sol-gel route and modified in a twostep reaction with a 2,2-bipyridine ligand molecule. The modified material was characterized by the BET method, elemental analysis and FTIR spectra and employed in $\mathrm{Cu}(\mathrm{II}), \mathrm{Cd}(\mathrm{II})$ and $\mathrm{Pb}(\mathrm{II})$ solid-phase extraction experiments. The developed method was applied in the preconcentration of metal species in a fresh water sample from Paraná River, Ilha Solteira, SP, Brazil, and its accuracy was evaluated by the comparison against a certified reference material (SRM 1643e).

\section{EXPERIMENTAL}

\section{Reagents and analytical solutions}

All the glassware used in the experiments was kept in an immersion bath of $\mathrm{HNO}_{3}$ solution $0.1 \%$ (v:v) for a period of 3 days. After this time, the material was rinsed in distilled water and deionized water. All the solutions were prepared with high purity chemicals and deionized water (Milli-Q system, Millipore). Hydrochloric and nitric acids were previously distilled in a sub-boiling system (Marconi).

Stock solutions of copper, cadmium and lead were prepared by dissolution of their respective salts in deionized water. The solutions and supernatant concentrations were determined directly by flame atomic absorption spectrometry (Analyst 700, Perkin Elmer) after stepwise dilution.

\section{Functionalization of silica gel}

Silica gel was prepared by the sol-gel route, as described in a previous work ${ }^{16}$. In the first reaction, $5 \mathrm{~g}$ of silica 
gel was suspended in $50 \mathrm{~mL}$ of $\mathrm{N}, \mathrm{N}$-dimethylformamide (DMF) and 0.0235 moles of silylating agent 3-chloropropyl-trimethoxysilane was added to the mixture. The reaction was performed in a nitrogen atmosphere at $423.15 \mathrm{~K}$ for $48 \mathrm{~h}$. The product obtained in the first step (Si-CTPS) was washed with ethanol and then subjected to a reaction with 0.0235 moles of 2,2-bipyridine ligand molecule in a nitrogen atmosphere at $423.15 \mathrm{~K}$ for 48 h. All the calculations took into account the presence of $4.6 \mathrm{OH}$ groups per square nanometer of silica. Figure 1 illustrates the two-step reaction involved in the functionalization of silica gel.

\section{Characterization}

The quantity of 2,2-bipyridine molecules bound to the silica surface was determined by nitrogen elemental analysis (Thermo Finnigan, Flash 1112 Series EA CHNS), while the FTIR spectra were collected on a Nicolet Nexus 670 FT-IR with a smart collector. The silica surface area was determined by the BET method ${ }^{20}$, based on the adsorption of gaseous nitrogen under several pressures at $77.74 \mathrm{~K}$, using an automated Micromeritics ASAP 2010 chemisorption analyzer.

\section{Solid Phase Extraction Experiments}

The purpose of the solid phase extraction experiments was to investigate some of the parameters related to metal/surface interaction. These parameters included the dynamic equilibrium at stirring times ranging from 1 to 30 minutes, the influence of $\mathrm{pH}$ on the extraction process, and the maximum extraction or sorption capacity of Si-BP modified material. A mass of $0.05 \mathrm{~g}$ of Si-BP used was used in all the experiments.

The dynamic equilibrium experiments were performed using the batch technique. $20 \mathrm{~mL}$ of metal solution were transferred to a volumetric flask and the volume was adjusted with deionized water. The contents of the flask were transferred to a conical flask and stirred for a given time. The mixture was filtered and the supernatant metal concentration determined by flame atomic absorption spectrometry (FAAS). The experiments to determine the influence of $\mathrm{pH}$ were carried out as explained above, with a stirring time of 10 minutes, and the $\mathrm{pH}$ of the solution was adjusted with diluted nitric acid and sodium hydroxide solution in a range of 1 to 5 . To determine the maximum adsorption capacity, the stirring time was set at 10 minutes, the $\mathrm{pH}$ of the solution at 5 , and the concentration of the metal solution was increased to $5.0 \times 10^{-3} \mathrm{~mol} \mathrm{~L}^{-1}$ for a final volume of $50 \mathrm{~mL}$.

\section{Column experiments}

The preconcentration factor (PF) for all metal species were determined in a continuous flow system using a micro column $(5 \mathrm{~mm}$ long and inner diameter of $2.0 \mathrm{~mm}$ ) packed with $15 \mathrm{mg}$ of Si-BP. The aliquots of $50 \mathrm{~mL}$ of metals species solutions $0.01 \mathrm{mg} \mathrm{L}^{-1}$, were percolated through the column at flow rate of $1.0 \mathrm{~mL}$ $\mathrm{min}^{-1}$ and then eluted with $1.0 \mathrm{~mL}$ of $\mathrm{HNO}_{3} 2.0 \mathrm{~mol} \mathrm{~L}^{-1}$, also at a flow rate of $1.0 \mathrm{~mL} \mathrm{~min}{ }^{-1}$. The eluates were collected in polyethylene flasks, followed by metals species determination by FAAS. After the determination of preconcentration factor the system was applied in the preconcentration of $50 \mathrm{~mL}$ of natural water sample, which was mineralized as described in a previously published work $^{21,22}$. This step was necessary to remove the influence of organic matter ${ }^{23}$.

\section{RESULTS AND DISCUSSION}

\section{Si-BP Characterization}

The amount of 2,2-bipyridine bound to the silica surface was $0.431 \mathrm{mmol}$ per gram of material. The specific surface area of bare silica was $614 \pm 7 \mathrm{~m}^{2} \mathrm{~g}^{-1}$, while that of the silica with the silylating agent and the modified one was $498 \pm 9$ and $450 \pm 5 \mathrm{~m}^{2} \mathrm{~g}^{-1}$, respectively. This lower surface area was due to the presence of pendant groups, which blocked the access of gaseous nitrogen molecules into the structure of the modified silica ${ }^{24,25}$. The FTIR spectra of pure silica, silica with silylating agent, and silica with 2,2-bipyridine molecule were recorded, as illustrated in Figure 2, to confirm the reactions depicted in Figure 1.

The Si-CPTS in Figure 2(a) presents three bands originating from $\mathrm{C}-\mathrm{H}$ stretching, which occurred in the region of $3000-2840 \mathrm{~cm}^{-1}$. These bands can be attributed to asymmetric $\left(\mathrm{v}_{\mathrm{as}} \mathrm{CH}_{2}\right)$ and symmetric $\left({ }_{\mathrm{vs}} \mathrm{CH}_{2}\right)$ stretching of methylenic (existing in the silyl structure).

A comparison of Si-CPTS and Si-BP indicated that the absorption bands slowly shifted to higher wave numbers, probably due to the influence of the aromatic ring. The
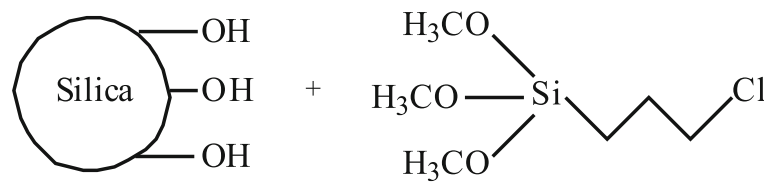

(CPT S)

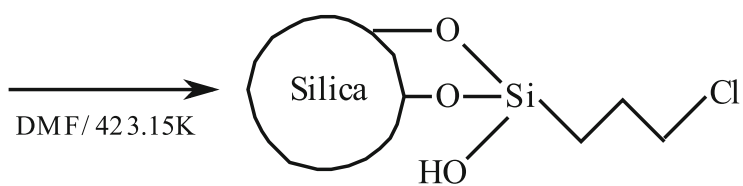

(Si-CPTS)

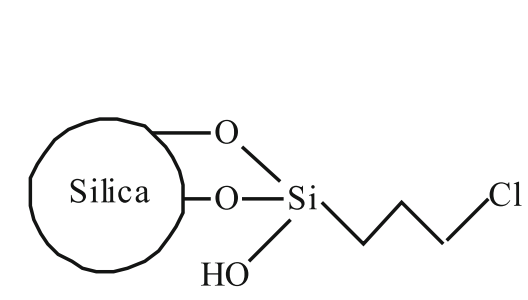

(Si-CPTS)

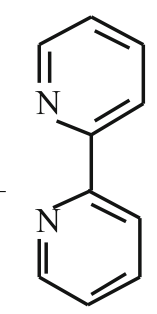

(BP)

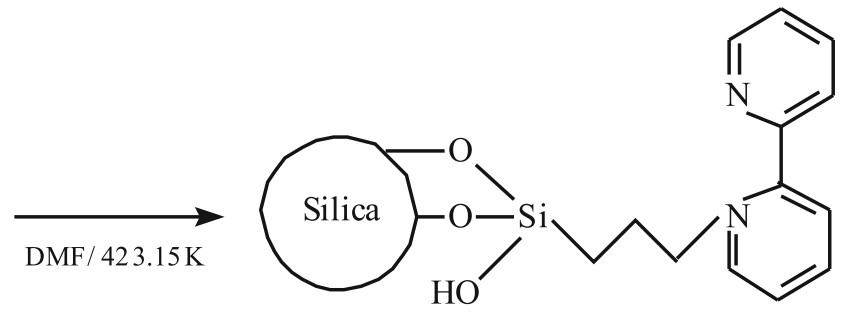

(Si-BP)

Figure 1. Reaction steps involved in silica surface modification with 2,2-bipyridine ligand 


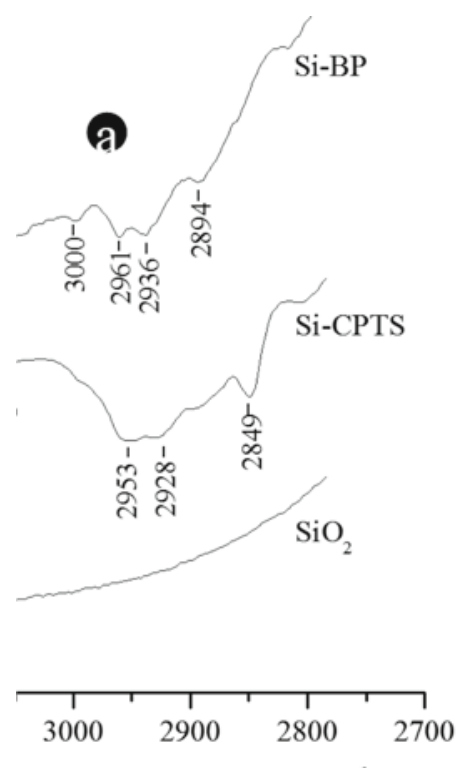

Wavenumber $\left(\mathrm{cm}^{-1}\right)$
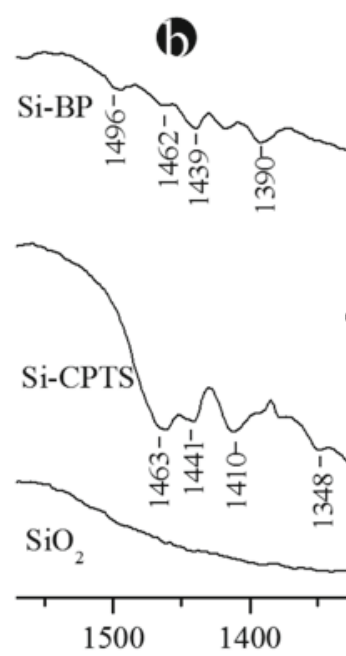

Wavenumber $\left(\mathrm{cm}^{-1}\right)$

Figure 2. Transmittance Fourier transform infrared spectra of pure silica ( $\mathrm{SiO} 2)$, silica with silylating agent ( $\mathrm{Si}$ CPTS), and silica with 2,2-bipyridine (Si-BP)

band appearing in the region of $3000 \mathrm{~cm}^{-1}$ was attributed to $\mathrm{C}-\mathrm{H}$ stretching vibration of $\mathrm{C}-\mathrm{H}$ from heteroaromatic molecules ${ }^{26}$. Figure 2(b) show FTIR spectra from 1600 to $1300 \mathrm{~cm}^{-1}$. Several absorption bands identified in the Si-CPTS spectrum were attributed to scissoring vibrations $\left(1463 \mathrm{~cm}^{-1}\right)$ and twisting and wagging vibrations (1348 $\mathrm{cm}^{-1}$ ) of methylenic groups. The same absorption bands were observed in the Si-BP spectrum, but ring stretching vibrations occurred in the general region between 1600 and $1300 \mathrm{~cm}^{-1}$ and the modification observed in this region was attributed to attachment of the 2,2-bipyridine molecule onto the silica surface.

\section{Solid phase extraction experiments}

An important aspect of solid sorbents is the rate at which the material adsorbs metal ions from solution and the time required for the system reach equilibrium. Figure 3 shows the extraction of $\mathrm{Cu}(\mathrm{II}), \mathrm{Cd}(\mathrm{II})$, and $\mathrm{Pb}(\mathrm{II})$ from an aqueous medium under different stirring times.

Figure 3 indicates that the kinetics involved in the adsorption of the metals ions under study was relatively fast, i.e., about 10 minutes, suggesting a good potential for application in column preconcentration procedures.

As it can be seen in Figure 4, the ability of Si-BP to extract metals is highly dependent on the $\mathrm{pH}$ of the solution. An increase in the concentration of $\mathrm{H}^{+}$species impaired adsorption, which can be explained by the protonation of adsorption sites on the ligand molecule. Experiments at $\mathrm{pH}$ exceeding 5 were not carried out due to the risk of undesirable hydrolysis and metal hydroxide precipitation.

The ability of Si-BP to extract the metal ions under study was characterized by its adsorption capacity, which was determined from the saturation range of the metal loading isotherms shown in Figure 5. The adsorption capacity (mmol g${ }^{-1}$ ) was calculated using equation (1): $N_{f}=\frac{n_{i}-n_{s}}{m}$

where $N_{f}$ is the number of metal moles adsorbed on the silica surface, $n_{i}$ and $n_{s}$ are the number of metal moles of

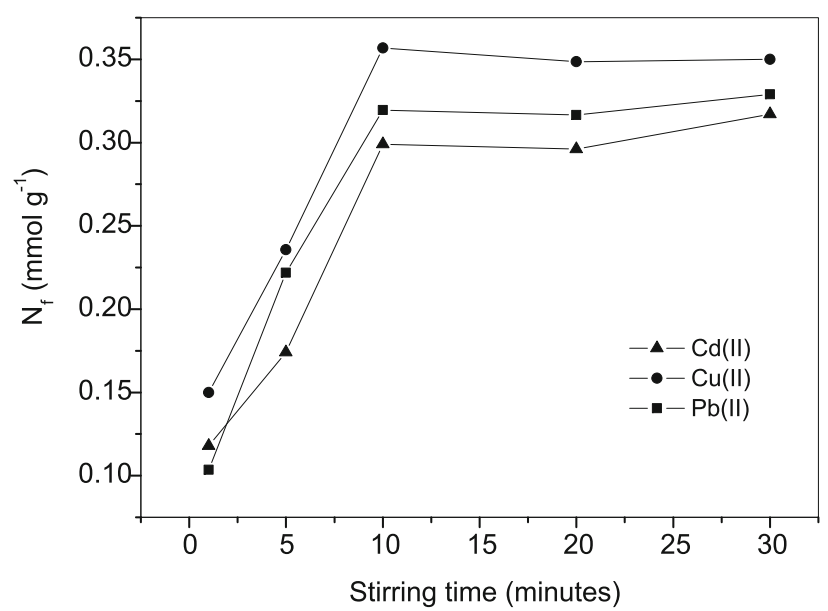

Figure 3. Dynamic equilibrium established by different stirring times in $\mathrm{Cu}(\mathrm{II}), \mathrm{Cd}(\mathrm{II})$, and $\mathrm{Pb}(\mathrm{II})$. Experimental conditions: Temperature $=27^{\circ} \mathrm{C}$; Si-BP mass $=0.05$ $\mathrm{g} ; \mathrm{pH}=5.0$.

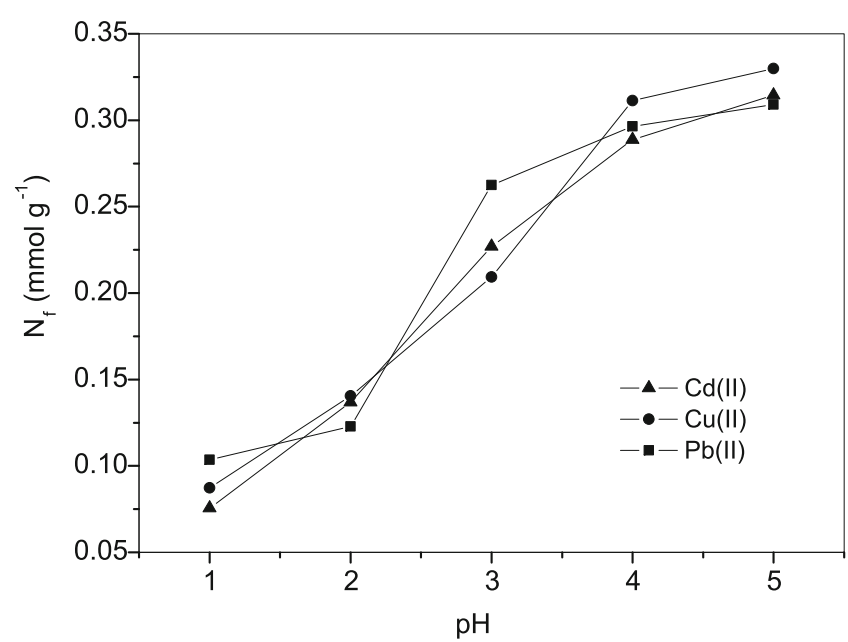

Figure 4. Influence of $\mathrm{pH}$ solution on the extraction process of $\mathrm{Cu}(\mathrm{II}), \mathrm{Cd}(\mathrm{II})$, and $\mathrm{Pb}(\mathrm{II})$. Experimental conditions: Temperature $=27^{\circ} \mathrm{C}$; Si-BP mass $=0.05 \mathrm{~g}$; Stirring time $=10$ minutes

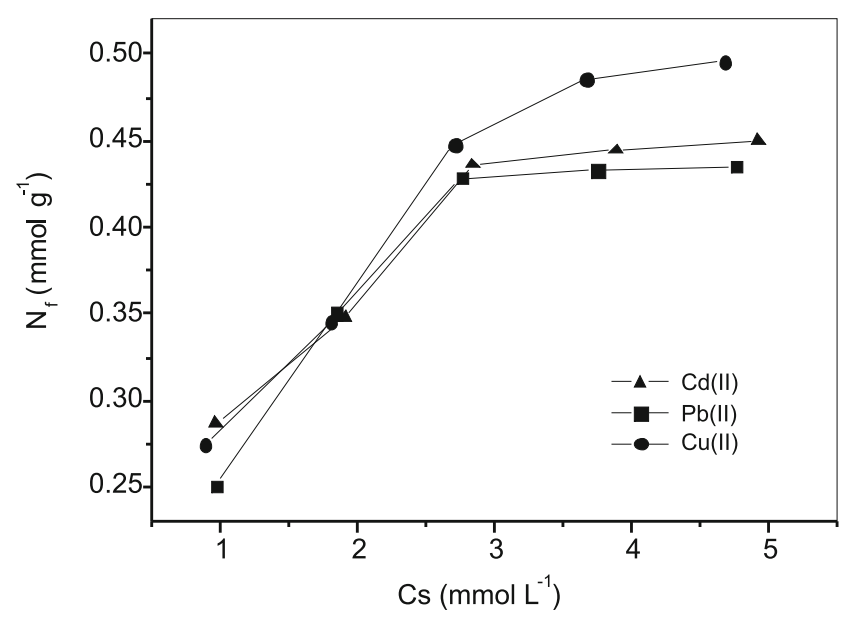

Figure 5. Microphotographs of the yarn structure and elementary cellulose fibres (device: Hitachi S-3400N scanning electron microscope). A, C, E - untreated jute; B, $\mathrm{D}, \mathrm{F}$ - jute treated with $1 \% \mathrm{KOH}$ water solution by $1 \mathrm{~h}$

the initial solution and of the supernatant after reaching equilibrium, and $m$ is the mass of modified silica, Si-BP, used here. According to equation (1), the values of $N_{f}$ obtained were $0.50,0.45$ and $0.43 \mathrm{mmol} \mathrm{g}^{-1}$ for $\mathrm{Cu}(\mathrm{II})$, $\mathrm{Cd}(\mathrm{II})$ and $\mathrm{Pb}(\mathrm{II})$, respectively. 
When adsorption remains constant, a monolayer should be formed, according to the modified Langmuir equation, and the metal maximum adsorption capacity can be estimated by equation (2):

$\frac{C_{s}}{N_{f}}=\frac{C_{s}}{N_{s}}+\frac{1}{N_{s} b}$

where $C_{s}$ is the concentration of the solution in equilibrium (mmol L $\left.{ }^{-1}\right), N_{f}$ is the concentration of metal ions adsorbed on the Si-BP surface, and $N_{s}$ represents the maximum amount of metal ions adsorbed per gram of material $\left(\mathrm{mmol} \mathrm{g}^{-1}\right)$. The adsorption studies were based on the linearized form of the adsorption isotherms illustrated in Figure 6.

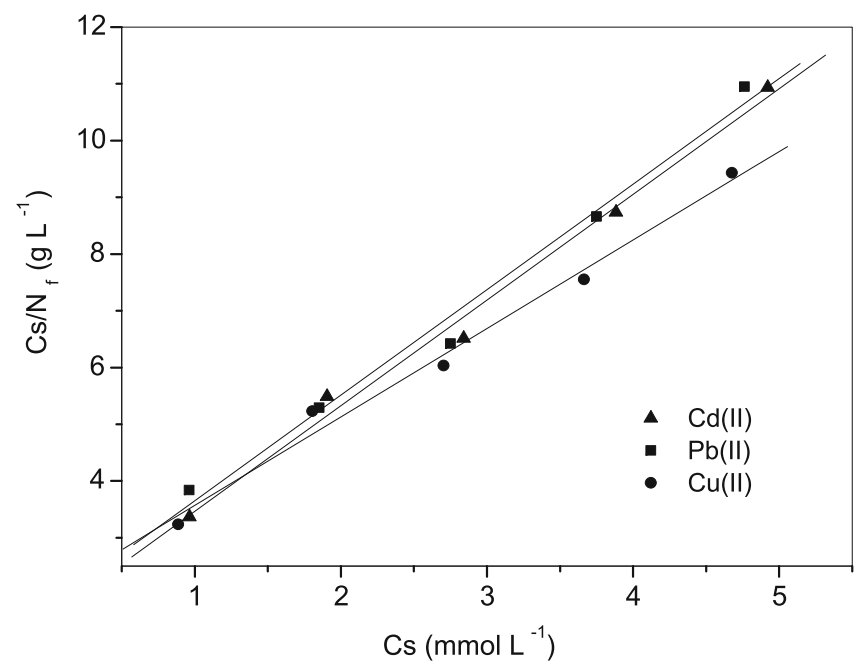

Figure 6. Linearized form of the adsorption isotherms for $\mathrm{Cu}(\mathrm{II}), \mathrm{Cd}(\mathrm{II})$. and $\mathrm{Pb}(\mathrm{II})$

The ratio at which the metal ions are bound to modified material can be estimated by equation $(3)^{\mathbf{1 4}}$ : $\phi^{\max }=\frac{N_{s}}{N_{o}}$

where $N_{o}$ is the amount of functional groups per gram of Si-BP. The values of $N_{o}, N_{f}$ and $N_{s}$ are presented in Table 1.

Table 1. $N_{o}, N_{f}$ and $N_{s}$ values obtained from $\mathrm{Cu}(\mathrm{II}), \mathrm{Cd}(\mathrm{II})$, and $\mathrm{Pb}(\mathrm{II})$ adsorption experiments

\begin{tabular}{|c|c|c|c|}
\hline Metal ions & $\mathrm{N}_{\mathrm{f}}\left(\mathrm{mmol} \mathrm{g}^{-1}\right)$ & $\mathrm{N}_{\mathrm{s}}\left(\mathrm{mmol} \mathrm{g}^{-1}\right)$ & $\mathrm{N}_{\circ}$ \\
\hline $\mathrm{Cu}(\mathrm{II})$ & 0.50 & 0.64 & 1.48 \\
\hline $\mathrm{Cd}(\mathrm{II})$ & 0.45 & 0.54 & 1.25 \\
\hline $\mathrm{Pb}(\mathrm{II})$ & 0.43 & 0.53 & 1.23 \\
\hline
\end{tabular}

Table 1 indicates that the maximum adsorption capacity of Si-BP was in good agreement with the experimental values, $N_{f}$. $\mathrm{Cu}(\mathrm{II})$, an intermediate acid according to Pearson's classification, showed higher adsorption values, which can be attributed to its affinity towards intermediate base nitrogen atoms ${ }^{19}$. $\mathrm{Cd}(\mathrm{II})$ and $\mathrm{Pb}(\mathrm{II})$ showed lower adsorption values than $\mathrm{Cu}$ (II), which, albeit not very significant, can be attributed to their lower affinity for nitrogen atoms. Another import point shown in Table 1 is that the type of metal-ligand complexes can be estimated from $N_{o}$ values. Since they are between 1.0 and 1.5 , it can be assumed that the complexes formed are of the type metal-ligand $=1: 1$, according to Figure 7 .

Through the comparison between the proposed material $\mathrm{Si}-\mathrm{BP}$ with other solid supports applied in the $\mathrm{Cu}(\mathrm{II})$, $\mathrm{Cd}(\mathrm{II})$ and $\mathrm{Pb}(\mathrm{II})$ sorption, presented in Table 2, is
Table 2. Comparison of $\mathrm{Cu}(\mathrm{II}), \mathrm{Cd}(\mathrm{II})$ and $\mathrm{Pb}(\mathrm{II}) \mathrm{Si}-\mathrm{BP}$ adsorption capacity with other related materials

\begin{tabular}{|l|c|c|c|c|}
\hline & \multicolumn{3}{|c|}{ Metal specie $\left(\mathrm{mmol}^{-1}\right)$} & \\
\hline $\begin{array}{l}\text { Type } \\
\text { material }\end{array}$ & $\mathrm{Cu}(\mathrm{II})$ & $\mathrm{Cd}(\mathrm{II})$ & $\mathrm{Pb}(\mathrm{II})$ & Ref. \\
\hline Si-AMP & 0.447 & 0.190 & 0.380 & {$[21,27]$} \\
\hline $\mathrm{Si}-\mathrm{LH}$ & - & 0.17 & 0.31 & {$[28]$} \\
\hline $\mathrm{Si}-\mathrm{D}$ & 0.442 & 0.135 & - & {$[29]$} \\
\hline $\begin{array}{l}\text { Si-BP } \\
\text { modified } \\
\text { silica }\end{array}$ & 0.64 & 0.54 & 0.53 & $*$ \\
\hline
\end{tabular}

* Data presented by the developed silica

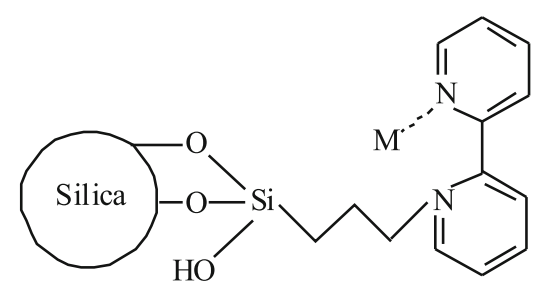

(Si-BP-Metal)

Figure 7. Proposed scheme for metal complexation by 2,2-bipyridine modified silica gel

possible to infer its advantages. Si-BP showed a high adsorption capacity compared with several materials.

\section{Preconcentration experiments}

The results achieved with the continuous flow system related to the natural river water preconcentration are congruent with the preconcentration factor obtained with metal standard solutions $\left(10 \mu \mathrm{g} \mathrm{L}^{-1}\right), 46,37$ and 36 fold for $\mathrm{Cu}(\mathrm{II}), \mathrm{Pb}(\mathrm{II})$ and $\mathrm{Cd}(\mathrm{II})$, respectively. These results and those obtained to standard reference material are summarized in Table 3.

According to Table 3 the preconcentration factor found when mineralized natural river water was subjected to the continuous flow system was the same determined with standard metal solution. In order to validated the

Table 3. Preconcentration results of metal solutions, standard reference material and natural river water

\begin{tabular}{|c|c|c|}
\hline \multicolumn{2}{|c|}{$\begin{array}{l}\text { Standard metal solution } \\
\qquad\left(\mu \mathrm{g} \mathrm{L}^{-1}\right)\end{array}$} & $\begin{array}{l}\text { Standard metal } \\
\text { solution after } \\
\text { preconcentration }\end{array}$ \\
\hline $\mathrm{Cu}(\mathrm{II})$ & \multirow{3}{*}{10} & $458.6 \pm 12.0$ \\
\hline $\mathrm{Pb}(\mathrm{II})$ & & $374.5 \pm 10.1$ \\
\hline \multirow[t]{2}{*}{$\mathrm{Cd}(\mathrm{II})$} & & $362.7 \pm 6.2$ \\
\hline & $\begin{array}{l}\text { Natural river water } \\
\left(\mu \mathrm{g} \mathrm{L}^{-1}\right)\end{array}$ & $\begin{array}{c}\text { Natural river water } \\
\text { after } \\
\text { preconcentration } \\
\left(\mu \mathrm{g} \mathrm{L}^{-1}\right)\end{array}$ \\
\hline $\mathrm{Cu}(\mathrm{II})$ & $40.025^{*}$ & $1834.52 \pm 32.6$ \\
\hline $\mathrm{Pb}(\mathrm{II})$ & $1.1539^{*}$ & $40.99^{*} \pm 2.7$ \\
\hline \multirow[t]{2}{*}{$\mathrm{Cd}(\mathrm{II})$} & $0.3654^{*}$ & $12.94^{*} \pm 0.6$ \\
\hline & $\begin{array}{c}\text { Standard reference } \\
\text { material } \\
\left(\mu \mathrm{g} \mathrm{L}^{-1}\right)\end{array}$ & $\begin{array}{l}\text { Standard reference } \\
\text { material after } \\
\text { preconcentration } \\
\left(\mu \mathrm{g} \mathrm{L}^{-1}\right)\end{array}$ \\
\hline $\mathrm{Cu}(\mathrm{II})$ & $22.7 \pm 0.3$ & $1075.67 \pm 28.1$ \\
\hline $\mathrm{Pb}(\mathrm{II})$ & $19.6 \pm 0.2$ & $709.36 \pm 13.4$ \\
\hline $\mathrm{Cd}(\mathrm{II})$ & $6.568 \pm 0.073$ & $245,33 \pm 10.9$ \\
\hline
\end{tabular}

*Determined by Atomic Absorption Spectrometry with Graphite Furnace 
method, aliquots containing $50 \mathrm{~mL}$, of certified reference material were preconcentrated in the same conditions applied to natural water and the results are also in agreement with the preconcentration factor, demonstrating that the system can be applied in the determination of trace levels of $\mathrm{Cu}(\mathrm{II}), \mathrm{Pb}(\mathrm{II})$ and $\mathrm{Cd}(\mathrm{II})$ in river water.

\section{CONCLUSIONS}

The proposed silica gel functionalization reaction was confirmed by the characterization techniques employed. In this case, the only possibility to anchor 2,2-bipyridine ligand molecules onto the Si-CPTS surface is through amine groups, which are good nucleophiles that react with chlorine groups. The Si-BP showed a good extraction capacity of $0.64,0.54$ and $0.53 \mathrm{mmol} \mathrm{g}^{-1}$ for $\mathrm{Cu}(\mathrm{II})$, $\mathrm{Cd}(\mathrm{II})$ and $\mathrm{Pb}(\mathrm{II})$, respectively, and fast kinetics for the metal ions of this study, which is an important characteristic in preconcentration and column experiments. The results of $\mathrm{Cu}(\mathrm{II}), \mathrm{Pb}(\mathrm{II})$ and $\mathrm{Cd}(\mathrm{II})$ preconcentration from natural river water showed that the system can be easily applied in trace metals determination taking into account the good preconcentration factor obtained, 46, 37 and 36 fold, respectively. Considering the classification of nitrogen atoms as an intermediate base, the material can be applied easily for the extraction of other metals with intermediate acid characteristics. This kind of material has interesting application in environmental area such as decontamination of natural water and in the determination of trace metals.

\section{Acknowledgements}

The authors thank FUNDUNESP (Proc. 00182/06DFP) and FAPESP (Proc. 06/54946-9) for their financial support of this research.

\section{LITERATURE CITED}

1. Minello, M.C.S., Paçó, A.L., Martines, M.A.U., Caetano, L., Santos, A., Padilla, P.M. \& Castro, G.R. (2009). Sediment grain size distribution and heavy metals determination in a dam on the Paraná River at Ilha Solteira, Brazil. J. Environ. Sci. Heal. A. 44, 861-865. DOI: 10.1080/10934520902958591.

2. Al-Khashman, O.A. \& Shawabkeh, R.A. (2006). Metals distribution in soils around the cement factory in southern Jordan. Environ. Pollut. 140, 387-394. DOI: 10.1016/j.envpol.2005.08.023

3. Minello, M.C.S., Paçó, A.L., Castro, R.S.D., Caetano, L., Padilha, P.M., Ferreira, G., Martines, M.A.U. \& Castro, G.R. (2010). Evaluation of heavy metal availability in contaminated sediments from the Ilha Solteira Hydroelectric dam on the Paraná River at Ilha Solteira, SP, Brazil. Fresen. Environ. Bull. 19, 2210-2214.

4. Pagnanelli, F., Moscardini, E., Giuliano, V. \& Toro, L. (2004). Sequential extraction of heavy metals in river sediments of an abandoned pyrite mining area: pollution detection and affinity series. Environ Pollut. 132, 189-201. DOI: 10.1016/j. envpol.2004.05.002.

5. Alabdula'aly, A. (1998). Trace metals in groundwater and treatment plant product water of the central region of Saudi Arabia. Desalination. 120, 163-168. DOI:10.1016/S00119164(98)00215-X.

6. Wang, L., Zhao, W., O'donoghue, M.B. \& Tan, W. (2007). Fluorescent nanoparticles for multiplexed bacteria monitoring. Bioconjugate Chem. 18, 297-301. DOI: 10.1021/bc060255n.

7. Yang, P., Quan, Z., Lu, L., Huang, S. \& Lin, J. (2008). Luminescence functionalization of mesoporous silica with different morphologies and applications as drug delivery systems. Biomaterials. 29, 692-702. DOI: 10.1016/j.biomaterials.2007.10.019.

8. Izquierdo-Barba, I., Ruiz-González, L., Doadrio, J. C., González-Calbet, J. M. \& Vallet-Regí, M. (2005). Tissue regeneration: A new property of mesoporous materials, Solid State Sci. 7, 983-989. DOI: 10.1016/j.solidstatesciences.2005.04.003.

9. Jang, J-K. \& Li, A. (2001). Separation of PCBs and PAHs in sediment samples using silica gel fractionation chromatography, Chemosphere. 44, 1439-1445. DOI: 10.1016/ S0045-6535(00)00463-X.

10. Ohta, K., Morikawa, H., Tanaka, K. \& Haddad, P.R. (1998). Non-suppressed ion chromatography of cations on silica gel modified with aluminium. J. Chromatography A. 804, 171-177. DOI: 10.1016/S0021-9673(97)01248-X.

11. Alcântara, I.L., Roldan, P.S., Margionte, M.A.L., Castro, G.R., Padilha, C.C.F., Florentino, A.O. \& Padilha, P.M. (2004). Determination of $\mathrm{Cu}, \mathrm{Ni}$ and $\mathrm{Pb}$ in aqueous medium by FAAS after preconcentration on 2-aminothiazole modified silica gel.. J. Brazil. Chem. Soc. 15, 366-371. DOI: 10.1590/ S0103-50532004000300005.

12. Ferreira, G., Caetano, L., Castro, R.S.D., Padilha, P.M. \& Castro, G.R. (2010). Synthesis, characterization, and application of modified silica in the removal and preconcentration of lead ions from natural river water. Clean Techn. Environ. Policy. DOI 10.1007/s10098-010-0322-4.

13. Oliveira, F.J.V.E., Filho, E.C.S., Melo, M.A.Jr. \& Airoldi, C. (2009). Modified coupling agents based on thiourea, immobilized onto silica. Thermodynamics of copper adsorption. Surf. Sci. 603, 2200-2206. DOI: doi:10.1016/j.susc.2009.04.020.

14. Castro, G.R., Oliveira, J.D., Alcântara, I.L., Roldan, P. S., Padilha, C.C.F., Prado, A.G.S. \& Padilha, P.M. (2007). Application of cellulose modified with p-aminobenzoic groups in preconcentration system for determination of $\mathrm{Cu}, \mathrm{Fe}, \mathrm{Ni}$, and $\mathrm{Zn}$ in fuel ethanol samples by flame atomic absorption spectrometry. Separ. Sci. Technol. 42, 1325-1340. DOI: 10.1080/01496390701242061.

15. Iler, R.K., The chemistry of silica, 1st edition (John Wiley \& Sons, New York, 1979).

16. Castro, G.R., Cristante, V.M., Padilha, C.C.F., Jorge, S.M.A., Florentino, A.O., Prado, A.G.S. \& Padilha, P.M. (2008). Determination of $\mathrm{Cd}(\mathrm{II}), \mathrm{Cu}(\mathrm{II})$ and $\mathrm{Ni}(\mathrm{II})$ in aqueous samples by ICP-OES after on-line preconcentration in column packed with silica modified with 2-aminothiazole. Microchim. Acta. 160, 203-209. DOI: 10.1007/s00604-007-0845-5.

17. Pérez-Quintanilla, D., Sánchez, A., Hierro, I., Fajardo, M. \& Sierra, I. (2009). Preconcentration of $\mathrm{Zn}$ (II) in water samples using a new hybrid SBA-15-based material. J. Hazard. Mater. 166, 1449-1458. DOI: 10.1016/j.jhazmat.2008.12.065.

18. Aguado, J., Arsuaga, J. M., Arencibia, A., Lindo, M., \& Gascón, V. (2009). Aqueous heavy metals removal by adsorption on amine-functionalized mesoporous sílica. J. Hazard. Mater. 163, 213-221. DOI: 0.1016/j.jhazmat.2008.06.080.

19. Pearson, G.R. (1963). Hard and softs acids and bases. J. Am. Chem. Soc. 85, 3533-3539. DOI: 10.1021/ja00905a001.

20. Brunauer, S., Emmett, P.H. \& Teller, E. (1938). Adsorption of gases in multi-molecular layers. J. Am. Chem. Soc. 60, 309-319. DOI: 10.1021/ja01269a023.

21. Pereira, A.S., Ferreira, G., Caetano, L., Martines, M. A. U., Padilha, P. M., Santos, A. \& Castro, G. R. (2010). Preconcentration and determination of $\mathrm{Cu}$ (II) in a fresh water sample using modified silica gel as a solid-phase extraction adsorbent. J. Hazard. Mater. 175, 399-403. DOI: 0.1016/j. jhazmat.2009.10.018.

22. Castro, R.S.D., Caetano, L., Ferreira, G., Padilha, P.M., Saeki, M. J., Zara, L.F., Martines, M.A.U., Castro, G.R. (2011). Banana peel applied to the solid phase extraction of copper and lead from river water: preconcentration of metal ions with a fruit waste. Ind. Eng. Chem. Res. 50, 3446-3451. DOI: 10.1021/ie101499e.

23. Romão, L.P.C., Castro, G.R., Rosa, H.A., Rocha, J.C., 
Padilha, P.M., Silva, H.C. (2003) Tangential-flow ultrafiltration: a versatile methodology for determination of complexation parameters in refractory organic matter from Brazilian water and soil samples. Anal. Bioanal. Chem. 375, 1097-1100. DOI:10.1007/s00216-002-1728-6.

24. Airoldi, C. \& Arakaki, L.N.H. (2001). Immobilization of ethylenesulfide on silica surface through sol-gel process and some thermodynamic data of divalent cation interactions. Polyhedron. 20, 929-936. DOI: 10.1016/S0277-5387(01)00743-4.

25. Moraes, F.V., Alcântara, I.L., Roldan, P.S., Castro, G.R., Margionte, M.A.L., Padilha, P.M. (2003). Determination of Cd (II) by FAAS in aqueous medium after preconcentration in line on a SiAT. Eclet. Quim. 28, 9-17. DOI: 10.1590/S010046702003000100001.

26. Silverstein, R.M., Bassler, G.C. \& Morril, T.C. (1994). Identificação espectrométrica de compostos orgânicos. Rio de Janeiro, Brasil: Guanabara Koogan.

27. Pereira, A.S., Ferreira, G., Caetano, L., Castro, R.S.D., Santos, A., Padilha, P.M. \& Castro, G.R. 4-amine-2-mercaptopyrimidine modified silica gel applied in $\mathrm{Cd}(\mathrm{II})$ and $\mathrm{Pb}(\mathrm{II})$ extraction from an aqueous medium. Pol. J. Chem. Tech. 12, 7-11. DOI: 10.2478/v10026-010-0002-5.

28. Bresson, C., Menu, M-J., Dartiguenave, M. \& Dartiguenave, Y. (2000). Triethoxysilyl-substituted aminoethanethiol ligands for zinc and cadmium complexes and aminoethanethiolmodified silica gel. Evaluation of the corresponding supported molecular trap for metallic pollutant uptake $\left(\mathrm{Cd}^{2+}, \mathrm{Hg}^{2+}\right.$ and $\left.\mathrm{Pb}^{2+}\right)$. J. Environ. Monit. 2, 240-247. DOI: 10.1039/B001408G.

29. Prado, A.G.S. \& Airoldi, C. (2001). Adsorption, preconcentration and separation of cations on silica gel chemically modified with the herbicide 2,4-dichlorophenoxyacetic acid. Anal. Chim. Acta. 432, 201-211. DOI: 10.1016/S00032670(00)01372-6. 